\title{
Conduta na ciência
}

\author{
Behavior-pattern in science
}

Pode-se dizer que os que se dedicam à atividade de pesquisa científica constituem classe profissional que se caracteriza por insaciável ânsia de busca de novos conhecimentos. Para eles, tudo que é publicado deve ser divulgado como dado original, ou seja, relativo a algum aspecto até então desconhecido na respectiva especialidade. Isso significa que, nessa inquirição da natureza, devem revelar-se eficazes e, ao mesmo tempo, assegurar-se da exclusividade, isto é, de que ninguém mais está perseguindo as mesmas questões. Em outras palavras, todo cientista deve estar a par do que está sendo feito sobre o problema que está pesquisando, sob pena de chegar atrás ou mesmo, desnecessariamente, chegar a conclusões já divulgadas.

Claro está que tais feições levam, inevitavelmente, à emulação, no bom sentido ou, no pior, à competição e à rivalidade. E em especial modo, em países cujo desenvolvimento científico já atingiu níveis nos quais a própria sobrevivência do pesquisador dependerá dos financiamentos que puder obter para as suas pesquisas. E eles, de maneira geral, dependem da produção consubstanciada na publicação de artigos originais em periódicos de bom nível. É pois compreensível que o esforço conjunto dos milhares de cientistas em todo o mundo esbarre nas fraquezas humanas sob a forma de desvios do comportamento científico.

Este problema tem sido objeto da atenção por parte de várias entidades e, principalmente, por ser do país líder mundial na produção científica da Academia Nacional de Ciências dos Estados Unidos (Alberts e col. 1994). Em relatório resultante de painel específico, identificaram-se três tipos de comportamento inadequado no ambiente de pesquisa que mereceram atenção. São eles, conduta imprópria na ciência, hábitos questionáveis na pesquisa e outras práticas inconvenientes, estas não peculiares à vida científica e que entram para o âmbito da legislação vigente. No primeiro tipo incluem-se atitudes variadas que vão desde a fabricação de dados, o plágio, a falsificação, até a sustentação de artigo provadamente indefensável. Tais situações desagüam, sem limites nítidos, nas condutas chamadas de questionáveis. Dentre estas, as mais comuns têm sido identificadas como desvios de orientação que levam à manipulação de dados, à apropriação indevida de idéias e material de pesquisa e à autoria imprópria. Esta última, pela freqüência com que é praticada, vem adquirindo feições consuetudinária.

Provavelmente, o motivo mais poderoso da autoria inadequada vem a ser a pressão à qual os pesquisadores estão sujeitos, no sentido de publicarem com frequiência. Eis que as avaliações e os acessos a toda uma carreira científica encontram-se, atualmente, alicerçadas nas listas de publicações dos últimos cinco anos. Além disso, cresce de vulto a importância que se dá, freqüentemente, de maneira errada, aos periódicos que as veiculam. Nesse particular, em nosso meio, o título de "periódico estrangeiro" e, principalmente, de edição em idioma inglês, adquire valor muitas vezes exagerado. Torna-se prática comum designar os nossos periódicos sediados em instituição oficial como sendo "da casa", depreciando-os com freqüência injustificada.

Seja como for, entende-se as tentativas dos profissionais de ampliar as suas reputações, para tanto publicando mais do que necessitam ou de que suas atividades justificam. Daí a avidez pela co-autoria em artigos de cujo conteúdo ignoram a maior parte e cujas conclusões, em decorrência, não podem discutir. Conseqüentemente, a inclusão de seus nomes na autoria desses artigos pouco contribui para os usuários apreciarem sua contribuição na feitura da pesquisa. Em outros termos, nesses casos extremos, a co-autoria transforma-se em mero reconhecimento por alguma contribuição quando da realização do trabalho. $O$ princípio básico vem a ser algo que cada autor figurante deveria ter a capacidade de resumir o conteúdo, 
quando de reunião pública. Pelo menos, em alguma parte do artigo publicado ou submetido à publicação. Nesse sentido, alguns propõem que, como primeiro passo, os próprios autores deveriam incluir breve tópico onde estivesse especificada a parte que coube a cada um (Maddox, 1994).

Seja como for, começam a ser dados os primeiros passos para apurar o comportamento científico. Atingir e manter alto nível de atividade científica constituem responsabilidades de todos os que dela participam. Não apenas, individualmente, os pesquisadores, mas também as instituições universitárias ou não e, em última análise, o poder público. Neste particular, os periódicos científicos podem e devem dar a sua parcela de contribuição, por todos os títulos valiosa. Ao elevarem o seu padrão de exigências, estarão propiciando o aperfeiçoamento da pesquisa científica em seus países.

\section{Oswaldo Paulo Forattini}

Editor

\section{Referências Bibliográficas}

ALBERT, B.; WHITE, R.M. ; SHIVE, K. Scientifique conduct. Proc. Natl. Acad. Sci. USA, 91: 3479-80, 1994. MADDOX, J. Making publication more respectable. Nature, 369: 353, 1994. 